\title{
Internal Marketing Activities in Higher Education
}

\author{
Shadi Altarifi ${ }^{1}$ \\ ${ }^{1}$ Marketing Department, University of Petra, Jordan \\ Correspondence: Shadi Altarifi, Marketing Department, University of Petra, Amman, Jordan. E-mail: \\ Saltarifi@uop.edu.jo
}

Received: March 20, 2014

Accepted: April 14, $2014 \quad$ Online Published: May 22, 2014

doi:10.5539/ijbm.v9n6p126

URL: http://dx.doi.org/10.5539/ijbm.v9n6p126

\begin{abstract}
The aim of this paper is to develop valid measurements to investigate the concept of 'Internal Marketing' (IM) in higher education institutions (HE). The study confirms that IM in HE can be measured using SIX multi-item components of: Employee Development, Internal Market Research, Internal Communications, Performance Incentives, Management Support and Vision about Excellent Service. The effect of IM on job satisfaction, organizational commitment and student satisfaction was also tested using Smart PLS. However, the findings indicate that although IM has a significant effect on job satisfaction and organizational commitment, its effect is not substantial, which means that there are other drivers of job satisfaction and organizational commitment. Therefore, future research is encouraged to identify those drivers. Moreover, the effect of job satisfaction and organizational commitment on student satisfaction is not substantial, which means that although these two variables are necessary, they are not sufficient conditions to ensure student satisfaction.
\end{abstract}

Keywords: internal marketing, student satisfaction, organizational commitment

\section{Introduction}

It is widely accepted that internal marketing (IM) is useful in developing and sustaining a culture within which customer-oriented behaviors should be emphasized, communicated, and rewarded (Arnett, Laverie, \& McLane, 2002).IM is also considered as a means to inform, educate, develop and motivate employees in order to accomplish the organisational objectives (Foreman and Money, 1995), and to facilitate employees' understanding of how individual objectives align with organisational goals to achieve organisational success in external markets (Mosley, 2007). Liao and Chuang (2004) concluded that when a market-oriented culture is developed within an organization, and the visions of that culture are well communicated throughout the organisation, employees become more aware of how their work fits in the broader scheme of organisational operations.

However, despite the relevance and the importance of the concept of IM to HEIs, it is still under research. More specifically, there is a lack of empirically grounded agreement to support the assumptions that IM practices as a means of satisfying and motivating employees' (Sasser \& Arbeit, 1976; Berry \& Parasuraman, 1991), or as methods for management of change and strategic implementation (Tansuhaj et al., 1987; Darling and Taylor, 1989), will motivate employees to engage in the adoption of a market-oriented strategy and to perform their jobs in a market-oriented manner (Awwad \& Agti, 2011; Harris, 1998; Martin et al., 1998; Kelley, 1992; Gummesson, 1991). Moreover, a review of the literature indicates that there is a dearth of studies that investigated the mechanisms, the applicability, the magnitude and the consequences of the concept of IM in HE.

The objectives of the current study are twofold: first it aims to investigate the concept of IM in HE sector through calibrating an IM model that is tailored specifically to the sector. Second, it aims to test the effect of IM on job satisfaction, organizational commitment and student satisfaction using a structural equation modeling. The remainder of the paper is organized as follows: in the second section, the multi-facet nature of IM will be discussed, in the following sections, hypotheses will be developed, the study's model will be proposed, and analysis and discussion will be provided. The last section will conclude and summarize the findings.

\section{Literature Review}

\subsection{The Multi-facet Nature of IM}

Since Berry et al. (1976) introduced the concept of IM; a variety of definitions have been proposed to discuss different aspects of the concept (see Rafiq \& Ahmed, 2000). For example, Berry (1981), Sasser and Arbeit (1976) 
and others (Gounaris, 2006; Lings \& Greenley, 2005; Berry \& Parasuraman, 1991) view IM as a means of satisfying employees through organisational commitment to produce value for the employees. Other researchers regard IM as a method for change management and strategic implementation through interfunctional communication and reducing conflict among departments (Tansuhaj, Wong \& McCullough, 1987; Darling \& Taylor, 1989; Rafiq and Ahmed, 1993; Gilmore and Carson, 1995; Cahill, 1995; Varey and Lewis, 1999). Yet, another camp of researchers considers IM as a way that leads to developing customer orientation in organisational employees to motivate them to develop MO behaviours and to be aware of the demands and needs of external markets (Papasolomou-Doukakis \& Kitchen, 2004; Frost \& Kumar, 2000; Quester \& Kelly, 1999; Lings \& Brooks, 1998; Richardson \& Robinson, 1986; Gronroos, 1985).

Despite the ample of different definitions of IM, there seems to be an agreement in the literature that IM has evolved around five major components; treating employees as internal customers, enabling employees to become customer oriented, human resource management-oriented view point, internal exchange and strategic tools (Gronroos, 1981; Papasolomou, 2006; Kelemen \& Papasolomou-Doukakis, 2004; George 1990; Dennis, 1995). On the basis of that, Rafiq and Ahmed put forward their definition which has been cited in literatures since then as the most comprehensive definition that capturesthe different aspects of IM. Rafiq and Ahmad (2000) defined the concept as follows:

"The planned effort, using marketing as an approach to the worker, that permits organisational resistance to change to be overcome, and is able to align, motivate, interfunctionally coordinate and integrate employees towards the effective implementation of functional and corporate strategies, so as to achieve the satisfaction of the external customer through a process that will make possible satisfied, motivated and customer oriented employees".

At the conceptualisation level, different attempts were made to identify the elements that capture the concept. A review of these attempts reveals that there are nine conceptualisations that were proposed to identify the key elements which make up IM (Tansuhaj, Wong, \& McCullough, 1987; Piercy \& Morgan, 1991; Tansuhaj, Randall, \& McCullough, 1991; Rafiq \& Ahmed, 1993; Gronroos, 1994; Foreman \& Money, 1995; Pitt \& Foreman, 1999; Finn et al., 1996; Ballantyne, 2000). For example, Tansuhaj et al. (1991) and Tansuhaj et al. (1987) conceptuallised IM as a multidimensional construct that consists of having positive attitudes towards employees, employee training and development, open environment for two-way communications, praise, recognition, and sharing sensitive customers policies with employees.

Through using the marketing mix concept (McCarthy, 1960), Piercy and Morgan (1991) conceptualise IM as the use of internal communications, price, products, and distribution to facilitate organizational change through political culture, power structure and techniques and systems within the organisation. By extending the work of Piercy and Morgan (1991), Rafiq and Ahmed (1993) depict that IM consists of internal products, internal promotion, internal price, internal distribution, and physical evidence (the workplace environment). Sharing similar aspects to the above conceptualisations, Ballantyne (2000), Finn et al. (1996) and others (Gronroos, 1994; Foreman \& Money, 1995) conceptualise IM as employee training and development, management support for IM, two-way communication, rewards, information dissemination, and employee involvement in policy, procedure, process development and customer service plans.

However, at the operational level, although a few attempts were madeto empirically identify the practices that are associated with the concept (Foreman \& Money, 1995; Lings \& Greenley, 2005; Keller, Lynch, Ellinger, Ozment \& Calantone, 2006), the literature seems to agree that vision about service excellence, employee development, internal market research, internal communications, management support and performance incentives are the key ones (Berry, Conant, Parasuraman, 1991; Finn et al. 1996; Berry \& Parasuraman, 1991; Gro"nroos, 1990, 1994; Cahill, 1995; Reynoso \& Moores, 1996; Pitt \& Foreman 1999; Tansuhaj et al., 1988; Hartline, Maxham, \& McKee 2000; Naude et al., 2003; Lee and Chen, 2005; Papasolomou \& Vrontis, 2006; Tasi $\&$ Tang, 2008). These six components are discussed in the following subsections.

\section{Hypotheses Development and the Suggested Model}

\subsection{Employee Development}

Employee development refers to the extent to which organisations view the development of knowledge and skills in employees as an investment, rather than a cost, and happens as an ongoing process (Foreman and Money, 1995). At the heart of IM is the notion of viewing employees as an internal market within a firm, and this internal market is fragmented into segment(s) that needs to be informed, educated, developed and motivated in order to accomplish the organizational objectives (Apasolomou-Doukakis, 2002; Berry \& Parasuraman, 1991). Hence, when an organization treats this market as the most valuable asset and/or as internal customers and seeks to 
improve job design and compensation, it is expected that the employees will become more satisfied (Zhou et al., 2011). It is also reasonable to expect that effective marketing directed towards this market will increase the organisation's ability to attract and retain the best qualified employees for the work (Hartline \& Ferrell, 1996; Bitner et al., 1994; Yoon et al., 2001).

Heskett et al. (1994) and Jaworski and Kohli (1993), arguing along these lines, indicate that the development of customer-focused staffing initiatives may not only lead the employees who intervene in the preparation and commercialisation of the provision of the service, but the employees at all levels of the organisation to develop market oriented behaviours. Also point out that investing in employees to motivate them to perform MO behaviours is a major consideration for organisations aiming to implement the marketing philosophy.

\subsection{Internal Market Research}

Internal market research refers to the extent to which organisations consider understanding the needs of the employees as a key priority (Lings \& Greenley, 2005). Information generation within the internal market appears to have three main facets: 1) identifying employees' perceptions of their inputs to their jobs, 2) identifying employees' perceptions of outputs (i.e., what they receive), and 3) identifying employees' perceptions of the equity of this exchange (Huseman \& Hatfield, 1990). Lings and Greenley (2005) note that internal market research involves identifying the benefits employees seek from their jobs, what they are prepared to give up in return, and what competitors are offering in terms of alternative employment. This knowledge can be used to make work environment more attractive to potential and existing employees than competitors' work environment (Berry, 1981; Stauss \& Schultze, 1990).

Organisations can generate information about their employees through formal written information generation, formal face-to-face information generation, and informal face-to-face information generation (Johlke \& Duhan (2000). The close physical proximity of managers and their front-line staff, provides scope for informal day-to-day, face-to-face interactions (Cobb et al., 1998). This offers additional opportunities for information generation.

\subsection{Internal Communications}

This factor refers to the full series of strategies that employees at different hierarchy levels use to communicate with each other regarding different organizational issues (Orsini, 2000; Papasolomou-Doukakis, 2002). A study conducted by Towers Watson (2010) among (384) employers in (22) different industries found that less than half of the companies were effective at communicating to employees, regarding how their actions affect the customer, or increase productivity. However, the study also reported that firmswhich were effective-employees communicators experienced $47 \%$ higher total returns to shareholders over the last five years, compared with those that were the least effective communicators. Hence, the importance of internal communication stems from its ability, through using marketing-like techniques, to create effective links between the efforts of senior management and staff and to facilitate employees' understanding of how individual objectives align with organizational goals, both of which are necessary conditions for achieving organizational success in its external markets (Grunig, Grunig and Dozier, 2002; Keller et.al., 2006).

In addition, researchers such as Piercy and Morgan (1990), Griffin and Hauser (1996) and Dougherty (1992) suggested that internal communications which act as a dialogue intended to convey feelings, perceptions and intentions of managers and employees regarding different organizational issues, can reduce inter-functional friction and departmental isolation, enhance cross-functional integration between the organisational employees and management and reduce language barriers between functions. This, in return, enhances the understanding of senior management about the objectives and priorities of other functions, and reduces "interfunctional misunderstandings due to differences in employees' thought worlds" (Dougherty, 1992).

\subsection{The Vision about Service Excellence}

It has been suggested that the vision about service excellence will influence the manner in which an organisation responds to its external markets (Pfau et al., 1991); carry the organisation to develop market-oriented responses to satisfy the needs and meet the requirements of its external markets (Wasmer \& Brunner, 1991); and stimulate employees to develop service consciousness and customer-oriented behaviour (Heskett, 1987; Pfeffer \& Veiga, 1999; Conduit \& Mavondo, 2001; Lings, 2004). George (1990), arguing along these lines, claims that visions about excellence of service influence the effectiveness of internal service encounters between employees and employers which is a necessary condition for the organisation to successfully compete in the external market. It is also suggested that strong and clear service visions enhance the organisational capability to serve customers (Ehrhart et al., 2011); influence how employees are served in their departments by the larger organization, and 
contribute to optimising the distribution of scarce resources throughout the network of locally operating units (Mills \& Ungson, 2001).

\subsection{Organisational Rewards}

A good manager helps sub-ordinates feel strong and responsible, rewards them properly for good performance, and sees that things are organized in such a way that subordinates feel they know what they should be doing" (McClelland \& Burnham, 1997). Organisational rewards (working conditions, salary, fringe benefits, pay, promotion opportunities) are those extrinsic rewards provided by the organisation which are aimed at motivating employee performance, eliciting commitment and maintaining membership (Jerome and Kleiner, 1995; LeBlanc \& Mulvey, 1998). Good working conditions are generally considered as a pre-requisite for good service quality as employees perform better when organisations create a climate of concern and caring (Schneider, White \& Paul, 1998).

Pay, satisfaction, and promotion opportunities also influence performance (Herzberg, 1966; Hallowell, Schlesinger \& Zornitsky, 1996; Lau, 2000). Carlsen (2003) believes that a motivated workforce is essential, as the complete participation of employees will inevitably drive the profitability of the organization. Certain academics have linked motivation as being a key determinant of job performance, and how a poorly motivated force will be costly in terms of excessive staff turnover, higher expenses, negative morale and increased use of managements' time (Jobber, 1994). Therefore, the management needs to know what exactly motivates their staff so that resources are not misallocated and dissatisfaction develops among employees (Jobber, 1994).

\subsection{Management Support}

Management support refers to executives who are visionary in realizing the importance of employees as customers in their organization. As Sakthivel and Raju (2006) point out, the top management should effectively communicate their directions/values/expectations to all strata of hierarchy, starting from the top level to the menial staff. They also noted that unless the principle of leadership permeates the length and breadth of the institution, and unless the command is well conceived and is well taken, an institution has very little chance of successful transformation into a market-oriented one. Management support would lead to promote better resource allocation, integrate decision-making and operational execution in relation to policy and practice in many areas, and empower organisational employees in becoming responsive to different constituents' needs (Porter \& Kramer, 2006; Eccles \& Krzus 2010; Porter \& Kramer, 2011).

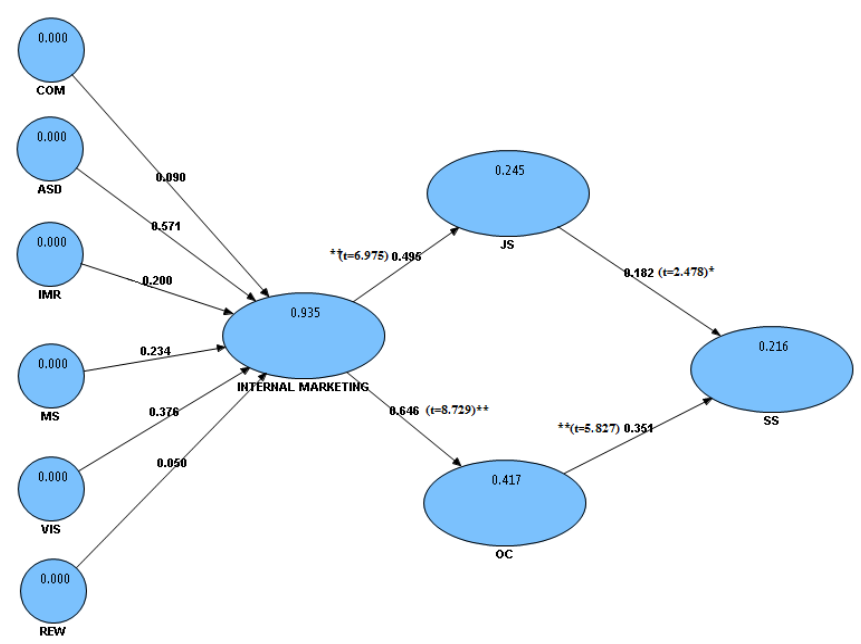

Figure 1. Summarizes the six constructs that form IM

Note. * Significant $(0.05),{ }^{*}$ Significant $(0.001)$.

Summarizes the six constructs that form IM. However, to confirm that IM is a valid and reliable construct, the following hypothesis is formulated:

H1: IM is a second-order construct made up of six first-order reflective constructs. 


\section{Consequences of Internal Marketing}

\subsection{Internal Marketing and Job Satisfaction}

Job satisfaction is defined here as an attitudinal reflection of how people like or dislike their jobs (Spector, 1997). From a marketing perspective, it has been suggested that employees should be treated on the basis of "customer-based" satisfaction principles (MacStravic, 2002) under the tent of IM (Peltier et al., 2003). In this regard, a paradigm shift is needed which advocates that $\mathrm{HE}$ institutions treat their employees as a significant "customer group" and a critical organizational asset (Gombeski et al., 2004).

As part of the IM perspective, it is important for employers to consider the needs of workers across all stages of the employee life-cycle, from "new hire" to "seasoned veteran" (Scovotti \& Peltier 2005). This sort of thinking makes it clear that, like any other service marketing situation, it is at least five times less costly to retain a customer (faculty member) than to find and recruit a new one (Murrow and Murrow, 2003). Organizations with a high degree of IM have ongoing processes in place for producing value for their employees through the effective management of the relationships between employees, supervisors and management (Gounaris, 2006). Melten et al. (2005) conceptualize employees as consumers of internal resources generated and supplied by others within the firm, with the ultimate focus being on ways to use these resources to improve the job characteristics that contribute to long-term commitment to the organization. Lings (2004) argues that when IM relates to activities such as the identification of exchanges of value for the employees, the comprehension of the labor market conditions, and the recognition of specific internal segments of employees with different characteristics, it will facilitate understanding of employees' needs and wants by the company's managers. This will make managers respond favorably to employee requests, which will result in subordinate attitudes and behaviors that enhance the employee/manager relationship (Shore \& Strauss, 2008).

It has been further suggested that IM which is fostered through internal market research (Sasser \& Arbeit, 1976), internal communication (Berry, 1981), effective internal exchanges (George 1990), and participative management and motivation and rewards (Foreman and Money 1995), and which aims to understand employee needs (Gronroos, 1983), develop jobs that attract and retain excellent service providers (Tansuhaj, Wong and McCullough, 1987), and deal with status and employee's concerns (William, 1977), will result in jobs (internal products) that satisfy the needs of employees (internal market), while satisfying the objectives of the organization (Berry, Hensel \& Burke, 1976).Following the logic of the above argument, the following hypothesis is proposed:

H2: Internal marketing activities directed towards academic staff will have a significant and positive effect on their level of satisfaction towards their jobs.

\subsection{Internal Marketing and Organizational Commitment}

Organizational commitment refers to the feeling of belonging; employees have towards the company, which consequently influences their ability to perform above and beyond expectations in achieving the company's goals (Castro, Armario, \& Del Rio, 2002). Mintzberg (1996) demonstrates that there is no substitute for human dedication, and that an organization without human commitment is like a person without a soul. According to Mintzberg, this is particularly true for what he terms client-oriented services "such as health care and education, which can never be better than the people who deliver them". Employees feel as if the company makes up part of their "family" and are willing to continually provide supportive behavior to uphold the company's values (Meyer \& Herscovitch, 2001). Beatty (1988) argues that a company's demonstrated employee and customer-oriented values serve to enhance the employee's attachment and commitment to the firm.

From a marketing perspective, Jaworski and Kohli (1993) made it unmistakably clear that organizational commitment is a direct consequence of IM. They explain that, because IM emphasizes the cooperation of all departments and individuals to achieve common goals, the cooperation process and accomplishment of these objectives should result in employees sharing a feeling of contribution to the firm. Consequently, employees gain a sense of pride in belonging to the firm, feel more satisfied with their jobs, and become more committed to the firm.

Caruana et al. (1999) found that employee commitment mediated the relationship between market orientation and performance. Similarly, Siguaw et al. (1994) found evidence that market orientation affects salespeople's orientation and their organizational commitment. Ruekert (1992) contended that these associations were important, since such positive job attitudes would lead to reduced employee turnover, enhanced flexibility, and improved productivity. Based on the above discussion, it is reasonable to hypothesize the following:

H3: Internal marketing activities directed towards academic staff will enhance their level of commitment 
towards their institutions.

\subsection{Job Satisfaction, Organizational Commitment and Employees' Perception of Student Satisfaction}

There is an increase emphasis on having satisfied and committed employees within service organizations due to the continuous interaction between service employees and their clients (Wright et al., 1997; Lings, 2004; Awwad \& Agti, 2011). Sarker, Crossman and Chinmeteepituck (2003), arguing along these lines, hold that satisfied workers will be more productive and remain within the organization longer, whereas dissatisfied workers will be less productive and more inclined to quit.The work of Schneider (1980) and Hartline and Ferrell (1996) also shows that job satisfaction is an important reason that employees offer good service, and that satisfied employees are more likely to deliver better service. Both job satisfaction and organizational commitment are associated with customer satisfaction (Wright et al., 1997; Sarker et al., 2003).

Thus, it is suggested that IM activities directed towards employees could inspire them, and that in return will be translated into better or enhanced service to the external customers of the organization (Mohr-Jackson, 1991; Tansuhaj et al., 1991). Marketing literature also implies that IM is capable of increasing work satisfaction, which, in turn, is a critical component in developing and sustaining employee satisfaction. The supposition is that if managers treat employees well, then employees will treat customers well (Gro"nroos, 1981\&1990; George, 1990). Based on the reviewed literature in this section, the following hypotheses are proposed:

H4: Job satisfaction resulting from internal marketing activities will have a significant and positive effect on student satisfaction.

H5: Organizational commitment resulting from internal marketing activities will have a significant and positive effect on student satisfaction.

\section{Research Methodology}

\subsection{Item Generation and Purification of Scale Items}

Previously validated scales were used to measure the variables in the current study. The items that measure that the six first-order indicators of IM were developed as follows: 'Vision', 'Academic Staff Development' and 'Rewards' were measured using 2, 6 and 6 items, respectively. All the items were borrowed from Foreman and Money (1995). 'Internal Communication' was measured using 6 items from Gounaris (2008) and Johlke \& Duhan (2001), while 'Management Support' was measured using 3 items from Edmiston-Strasser (2009), and 7 items were borrowed from Lings (2005) to measure 'Internal Market Research'. With regard to the three consequences of IM; 'Job Satisfaction' was measured using 5 items from Brayfield and Rothe(1951) and Weiss, Dawis, England, and Lofquist (1967), while organizational commitment was measured using 7 items from Mowday et al. (1979), and 6 items were borrowed from to measure 'Employees' Perception of Student Satisfaction'.

A questionnaire containing the 48 items designed to assess the measure's properties was then emailed to 8 experts to review the items. After receiving three questionnaires and on the basis of the detailed comments, items were modified accordingly. The revised scaleswere then subjected to another stage of pretesting by asking 20 academic staff in two major universities in the Middle East to further comment on the research instrument. The final structured questionnaire consisted of 48 items and respondents were asked to express their level of agreement based on a five-point Lickert scale running from very strongly disagree up to very strongly agree.

\subsection{Data Collection}

The population was all Jordanian HEIs with university status. No sampling procedures were carried out as surveying all 21 HEIs was feasible. The sampling unit was the university and the respondents were the academic staff. The empirical data was collected over a period of three months (October, November and December, 2013) by means of a self-administrated questionnaire. Out of the 900 questionnaires that were delivered to the academic staff across the (21) universities, (522) questionnaires were returned, bringing the response rate to (58\%). The adopted method of data collection was Drop-and-Collect or the so- called "Drop-Off" (Aaker et al. 2004). Field workers were fully briefed about the operating procedures of this method, which were mainly based on personally delivering and collecting questionnaires from respondents. After excluding 38 questionnaires, 484 usable ones remained for the final data analysis.

\subsection{Data Analysis: Validating First-Order Indicators of Internal Marketing}

Internal Marketing Index (IMI) was validated at two stages. In the first stage, the six first-order reflective indicators were validated: Internal Communication, Vision, Academic Staff Development, Rewards, Internal Market Research and Management Support. In the second stage, IMI was validated as a second-order formative 
construct consisting of six first-order reflective indicators.

To validate the six first-order indicators, reliability tests were first conducted, which resulted in deleting one item was deleted because it was below the threshold of 0.35 (Churchill, 1979; Nunnally, 1978). The results of reliability test, which are reported in table 1, also indicate that the overall coefficient alpha and the values of all the individual scales well exceeded the obligatory requirements of 0.70 (Churchill, 1979; Nunnally, 1978) (see table1).

Table 1. Reliability analysis and average variance extracted of the six first-order indicators

\begin{tabular}{|c|c|c|c|c|}
\hline Code & Variables & $\begin{array}{l}\text { Cronbach } \\
\text { Alpha }\end{array}$ & $\begin{array}{l}\text { Composite } \\
\text { Reliability }\end{array}$ & AVE \\
\hline & Internal Communication: & 0.865 & 0.931 & 0.870 \\
\hline IC1 & Management arranges regular meetings to listen to the employees. & .613 & & \\
\hline $\mathrm{IC} 2$ & $\begin{array}{l}\text { 2. The University places considerable emphasis on communicating with our } \\
\text { employees }\end{array}$ & .795 & & \\
\hline IC3 & 3. Our university communicates to employees the importance of their service roles & .756 & & \\
\hline IC4 & $\begin{array}{l}\text { 4. My employer communicates to me how my job tasks fit into the overall } \\
\text { university effort }\end{array}$ & .517 & & \\
\hline IC5 & 5. The University often announces new policies to us by holding meetings. & .713 & & \\
\hline \multirow[t]{2}{*}{ IC6 } & $\begin{array}{l}\text { 6. Information about government action affecting my university is well } \\
\text { communicated }\end{array}$ & .589 & & \\
\hline & Vision: & 0.849 & 0.931 & 0.832 \\
\hline VIS1 & The University offers employees a vision that they can believe in & .744 & & \\
\hline \multirow[t]{2}{*}{ VIS2 } & The University communicates the University's vision well to employees & .694 & & \\
\hline & Academic Staff Development: & 0.890 & 0.916 & 0.645 \\
\hline ASD1 & The University prepares our employees to perform well & .767 & & \\
\hline ASD2 & $\begin{array}{l}\text { 2. The University views the development of knowledge and skills in employees as } \\
\text { an investment rather than a cost }\end{array}$ & .732 & & \\
\hline ASD3 & $\begin{array}{l}\text { 3. Skill and knowledge development of employees happens as an ongoing process } \\
\text { in our university }\end{array}$ & .726 & & \\
\hline ASD4 & $\begin{array}{l}\text { 4. The University teaches our employees "why they should do things" and not just } \\
\text { "how they should do things" }\end{array}$ & .647 & & \\
\hline ASD5 & $\begin{array}{l}\text { 5. This university has the flexibility to accommodate the differing needs of } \\
\text { employees }\end{array}$ & .610 & & \\
\hline \multirow[t]{2}{*}{ ASD6 } & $\begin{array}{l}\text { 6. In this university, the employees are properly trained to perform their service } \\
\text { rolls }\end{array}$ & .676 & & \\
\hline & Rewards: & 0.917 & 0.925 & 0.861 \\
\hline REW1 & $\begin{array}{l}\text { 1. The University measures and rewards employee performance that contributes } \\
\text { most to our university's vision }\end{array}$ & .794 & & \\
\hline REW2 & $\begin{array}{l}\text { 2. Our performance measurement and reward system encourages employees to } \\
\text { work together }\end{array}$ & .676 & & \\
\hline REW3 & $\begin{array}{l}\text { 3. In our university, those employees who provide excellent service are rewarded } \\
\text { for their efforts }\end{array}$ & .749 & & \\
\hline REW4 & The University is aware about the need of motivation. & .787 & & \\
\hline REW5 & The University is aware about positive effects of motivation. & .700 & & \\
\hline \multirow[t]{2}{*}{ REW6 } & Reward is systematic according to the job evaluation & .664 & & \\
\hline & Internal Market Research: & 0.794 & 0.861 & 0.554 \\
\hline IMR1 & $\begin{array}{l}\text { 1. Management is aware of its employees' needs and expectations about the } \\
\text { University }\end{array}$ & .541 & & \\
\hline IMR2 & $\begin{array}{l}\text { 2. The University regularly evaluates our employees' satisfaction with their work } \\
\text { situation }\end{array}$ & .656 & & \\
\hline IMR3 & We are aware of the personnel policies that are applied by the competition & .501 & & \\
\hline IMR4 & $\begin{array}{l}\text { 4. Management is aware of the characteristics of the labor market in its sector of } \\
\text { activity. }\end{array}$ & .573 & & \\
\hline IMR5 & 5. The University is aware of which universities have the potential of attracting & .630 & & \\
\hline
\end{tabular}


away our key employees.

IMR6 $6 . \quad$ Our university's personnel policy considers the characteristics of each group of
employees

\begin{tabular}{llllll} 
IMR7 & 7. & Management in our university is willing to listen to employees' problems & .656 & $\mathbf{0 . 8 6 8}$ & $\mathbf{0 . 9 1 9}$ \\
\hline
\end{tabular}

MS1 1. The senior executive team of the university receive regular reports that evaluate the extent to which internal marketing activity (e.g. employee development, internal communications, internal market research) is contributing to achieving agreed objectives

MS2 2. The agenda of senior executive team of the university typically includes discussion regarding the effectiveness of internal marketing activity(e.g., employee development, internal communications, internal market research) and the related issues that contextualise this.

MS3 3. The internal marketing strategy is formally discussed and approved by the executive team of the university who ensure it is integrated and not simply functional in scope

After that, a six-factor model was established using exploratory factor analysis (EFA) to determine the questions that best measure the six first-order indicators of IMI. One item was also deleted because of cross loadings. Table 2 shows that the clear structures of the 6 -factor explained $64.72 \%$ of the variance in the construct of IM and that all items loaded significantly (loadings ranging from 0.516 to 0.813 ) on their respective factors, which was an indication of having clear 6-factors. In addition, it was noticed that the first factor (REW) had a relatively much higher eigenvalue of 13.06 with variance explained of $43.56 \%$. It was also noticed

As far as convergent validity is concerned, it was assessed by observing the average variance extracted (AVE) index using Smart PLS (Wetzels et al., 2009). On the other hand, discriminant validity was assessed by the Fornell-Larcker criterion using Smart PLS (Fornell \& Larcker, 1981). The findings of analysis reported in Table 2 and 3 show that the SIX first-order reflective indicators have adequate convergent and discriminant validity.

Table 2. Factorial analysis, six-factor model

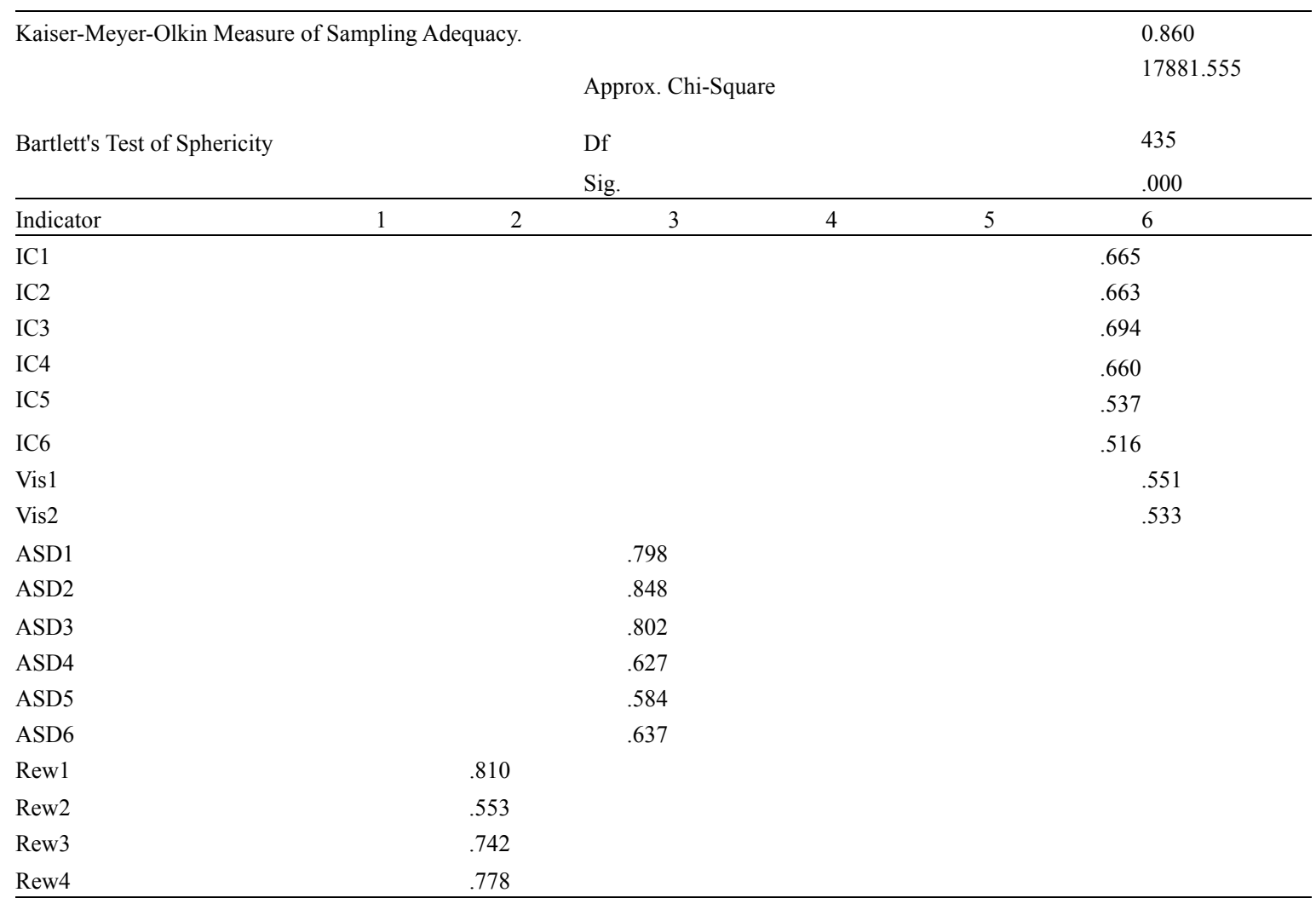




\begin{tabular}{|c|c|c|c|c|c|c|}
\hline Rew5 & & 98 & & & & \\
\hline Rew6 & & 64 & & & & \\
\hline IMR2 & & & & & & \\
\hline IMR3 & & & & & & \\
\hline IMR4 & & & & & & \\
\hline IMR5 & & & & & & \\
\hline IMR7 & & & & & & \\
\hline MS1 & & & & & & \\
\hline MS2 & & & & & & \\
\hline MS3 & & & & & & \\
\hline EGIENVALUE & 13.06 & 2.35 & 2.08 & 1.47 & 1.10 & 1.02 \\
\hline VARIANCE (70.13\%) & 43.56 & 7.86 & 6.72 & 4.91 & 3.69 & 3.37 \\
\hline
\end{tabular}

Table 3. First-order reflective indicators-fornell-larcker criterion

\begin{tabular}{lrrrrrr}
\hline & ASD & COM & IMR & MS & REW & VIS \\
\hline ASD & 1 & & & & & \\
COM & 0.6156 & 1 & & & & \\
IMR & 0.5394 & 0.5579 & 1 & & & \\
MS & 0.4414 & 0.5088 & 0.6694 & 1 & & \\
REW & 0.5222 & 0.5015 & 0.58 & 0.4981 & 0.4097 & 1 \\
VIS & 0.6159 & 0.5963 & 0.5475 & 0.5268 & & \\
\hline
\end{tabular}

\subsection{Data Analysis: Validating Formative Constructs}

To assess IMI as a second-order formative construct, the researcher constructed IMI as hierarchical latent variable model using the repeated indicator approach. In addition, two criteria: external validity and multicollinearity were used to validate formative measurement model of IMI (see table4). Based on the statistical analysis of the SIX first-order indicators, and IMI as a second-order formative construct, it is confirmed that IMI is a second-order construct that consists of six first-order reflective indicators. Therefore, H1 is accepted.

Table 4. IMI as a second-order formative construct: external validity and VIF

\begin{tabular}{|c|c|c|c|c|c|c|c|c|c|c|}
\hline \multicolumn{11}{|c|}{ Internal Marketing Index } \\
\hline & \multicolumn{8}{|c|}{ External Validity (Correlation) } & \multicolumn{2}{|c|}{ Multicollinearity } \\
\hline & IC & VIS & ASD & REW & IMR & MS & IMI & & Tolerance & VIF \\
\hline IC & 1 & & & & & & & IC & .384 & 2.603 \\
\hline VIS & $.631^{* *}$ & 1 & & & & & & VIS & .488 & 2.050 \\
\hline ASD & $.660^{* *}$ & $.611^{* *}$ & 1 & $.550^{* *}$ & $.539^{* *}$ & $.439^{* *}$ & $.805^{* *}$ & ASD & .478 & 2.091 \\
\hline REW & $.665^{* *}$ & $.482^{* *}$ & $.550^{* *}$ & 1 & $.625^{* *}$ & $.536^{* *}$ & $.852^{* *}$ & REW & .457 & 2.190 \\
\hline IMR & $.574^{* *}$ & $.548^{* *}$ & $.539^{* *}$ & $.625^{* *}$ & 1 & $.664^{* *}$ & $.804^{* *}$ & IMR & .424 & 2.358 \\
\hline MS & $.519^{* *}$ & $.528^{* *}$ & $.439^{* *}$ & $.536^{* *}$ & $.664^{* *}$ & 1 & $.698^{* *}$ & MS & .504 & 1.982 \\
\hline IMI & $.865^{* *}$ & $.729^{* *}$ & $.805^{* *}$ & $.852^{* *}$ & $.804^{* *}$ & $.698^{* *}$ & 1 & & & \\
\hline
\end{tabular}

Note. Correlation is significant at the 0.01 level (2-tailed)

With regard to $\mathrm{H} 2$, figure 2 shows that the path coefficient from IMI to job satisfaction was significant $(\beta=0.495$, $\mathrm{P}<0.001, \mathrm{R}^{2}=0.245$ ), thus, the hypothesis is accepted. However, it is worth noting that the relatively low $\mathrm{R}^{2}$ indicates that IM is not a strong driver of job satisfaction, though the relationship is significant. Such a finding also reveals that there are stronger drivers to job satisfaction in university-setting other than IM, thus, future research is encouraged to identify those drivers.

Regarding $\mathrm{H} 3$, the figure shows that the path coefficient from IMI to organizational commitment was also significant $(\beta=0.646, \mathrm{P}<0.001)$ and the variance in organizational commitment that was explained by IMI was relatively moderate $\left(\mathrm{R}^{2}=0.417\right)$. . Hence the hypothesis is accepted. However, it could be concluded from both 
hypotheses that academic staff in HEIs that implement and practice the constructs of IM tend to have stronger satisfaction and commitment to their organizations compared with HEIs that do not.

With regard to $\mathrm{H} 4$, the figure shows that both job satisfaction $(\beta=0.182, \mathrm{t}=2.478)$ and organizational commitment $(\beta=0.351, t=5.827)$ have positive and significant effects on student satisfaction. Nonetheless, it is worth noting that the variance in student satisfaction that was explained by job satisfaction and organizational commitment was relatively low $\left(\mathrm{R}^{2}=0.216\right)$, indicating that there are other important variables that contribute to student satisfaction, and future research is encouraged to identify those variables.

\section{Discussion and Conclusions}

The current study confirms that IM is a second-order formative construct that consists of six first-order reflective constructs. The study also confirms that the measurement instrument for IM is the 28 items which can be measured using the SIX multi-item components of: Internal Communications, Vision about Excellent Service, Employee Development, Performance Incentives, Internal Market Research and Management Support. In addition, the SIX first-order indicators of IM, which demonstrated the construct and criterion validated, were closely related and exhibited a high level of interdependence and strong convergence towards the overall index. The valid and reliable first-order indictors of IM index when seen as a whole, seem to have a more significant and positive influence on the criterion variables (i.e., job satisfaction and organizational commitment). Moreover, the instrument that measures this index, which is intentionally developed to build more market-driven institutions, can be effectively used to monitor the level of commitment of HE institutions in serving the staff market.

On a broader view, the findings also provide significant support for IM literature which advocates that the six constructs that form IM have an influence upon job satisfaction and organizational commitment in HEIs. With regard to the second hypothesis, the finding was expected because HEIs that are internally market-oriented will seriously try to understand staff current and future needs and wants, discuss or share among the various functional units about staff needs, and respond rapidly to meet those needs. Those institutions also understand that different groups of staff have different needs, and therefore, they will seriously try to differentiate the services provided to them both in content and style. With regard to the third hypothesis, the finding indicates that HEIs that implement the constructs of IM help in creating and developing more committed staff. Such a finding corresponds to results of previous researches in this regard especially studies of Ahmed and Rafiq, Morgan, Fombern and Guest. The findings of the current research also reveal that a requirement for survival and growth is that both the HEIs and their staff, academicians in particular have an interest in their joint relationship - leading to a win-win effect. Factors such as development, communications and incentives are playing a core role in enhancing the academician's satisfaction and commitment.

The results are timely, especially for HEIs leaders. This is because the landscape of the HE industry has dramatically changed in recent years, especially in this global economy where human capital of HEIs have become unstable, and therefore, there is a high risk of brain drain in those HEIs that do not invest in their human capital. Moreover, in this hostile environment, HEIs have to produce and disseminate knowledge in an environment characterized by growing and intense competition among HEIs, which mainly focusing on attracting valuable professors. Accordingly, the SIX constructs that form IM and their hypothesized effects, correspond to these challenges through increasing staff retention and enhancing their satisfaction.

However, regarding the last hypothesis, it was concluded that although job satisfaction and organizational commitment had significant effect on student satisfaction, their effect is necessary but not sufficient. This means that there are other important drivers of student satisfaction, and therefore, future research is encouraged to identify such drivers.

\section{References}

Aaker, D., Kumar, V., \& Day, G. (1995). Marketing Research (5th ed.). John Wiley \& Sons, New York.

Arnett, B., Laverie, D., \& McLane, C. (2002). Using job satisfaction and pride asinternal- marketing tools. Cornell Hotel and Restaurant Administration Quarterly, 87-96. http://dx.doi.org/10.1016/S0010-8804(02)80035-0

Awwad, M., \& Agti, D. (2011). The impact of internal marketing on commercial banks' market orientation. International Journal of Bank Marketing, 29(4), 308-332. http://dx.doi.org/10.1108/02652321111145943

Barnes, B. (2004). Exploring the linkage between internal marketing, relationship marketing, and service quality. Total Quality Management and Business Excellence, 15(5/6), 593-603. 
Bartlett, M. (1954). A note on the multiplying factors for various chi square approximations. Journal of the Royal Statistical Society, 16(series B), 296-298. http://dx.doi.org/10.1080/14783360410001680080

Berry, L. (1981). The employee as customer. Journal of Retail Banking, 13, 268-280.

Berry, S., \& Marian, B. (1976). Improving Retailer Capability for Effective Consumerism Response. Journal of Retailing, 52(3), 3-14.

Berry, L., \& Parasuraman, A. (1991). Marketing Service, Competing through Quality. The Free Press: New York.

Berry, L., Conant, J., \& Parasuraman, A. (1991). A Framework for Conducting a Services Marketing Audit. Journal of the Academy of Marketing Science, 19(Summer), 255-268. http://dx.doi.org/10.1007/BF02726500

Castro, C., Armario, E., \& Rio, M. (2005). Consequences of market orientation for customers and employees. European Journal of Marketing, 39(5/6), 646-675. http://dx.doi.org/10.1108/03090560510590755

Churchill, Jr. (1979). A paradigm for developing better measures of marketing constructs. Journal of Marketing Research, 16, 64-73. http://dx.doi.org/10.2307/3150876

Church, A., \& Waclawski, J. (2001). Designing and using organizational surveys: A seven-step process. San Francisco: Jossey-Bass.

Cobb, J., \& Gibbs, J. (1990). A new competency-based, on-the-job programme for developing professional excellence in engineering. The Journal of Management Development, 9(3), 60-72.

Constantin, B. C. (2009). THE INTELLECTUAL CAPITAL OF UNIVERSITIES. Academy of Economic Studies, Bucharest, 63-70.

Darling, R., \& Taylor, R. (1989). A model for reducing internal resistance to change in a firm's international strategy. European Journal of Marketing, 23(7), 34-41.

Davies, P., \& Scribbins, K. (1985). Marketing Further and Higher Education. York: Longman Group Ltd.

Di Gregorio, D., \& Shane, S. (2006). Why do some universities generate more start-ups than others? In Donald Siegel (Ed.), Cheltenham. UK: Edward Elgar Publishing.

Dougherty, D. (1992). Interpretive barriers to successful product innovation in large firms. Organization Science, 3, 179-203.

Ehrhart, K. H., Witt, L. A., Schneider, B., \& Perry, S. J. (2011). Service Employees Give as They Get: Internal Service as a Moderator of the Climate-Service Outcomes Link. Journal of Applied Psychology, 96(2), 423-431

Fazlagic, A. (2009). Measuring the intellectual capital of a university. Paper presented at the Trends in the Management of Human Resources in Higher Education. Poznan.

Foreman, S., \& Money, A. (1995). Internal marketing: concepts, measurement and application. Journal of Marketing Management, 11(8), 755-768. http://dx.doi.org/10.1080/0267257X.1995.9964388

Fornell, C., \& Larcker, D. F. (1981). Evaluating structural equation models with unobservable variables and measure. Journal of Marketing Research, 18, 39-50. http://dx.doi.org/10.2307/3151312

Frost, F., \& Kumar, M. (2000). INTSERVQUAL: an internal adaptation of the GAP model in a large service organization. Journal of Service Marketing, 14(5), 358-377. http://dx.doi.org/10.1108/08876040010340991

Garson, D. (2004). Statnotes: An online textbook. Retrieved from http://www2.chass.ncsu.edu/garson/pa765/statnote.htm

Gatfield, T., Barker, M., \& Graham, P. (1999). Measuring communication impact for university advertising materials. Corporate Communications: An international Journal, 4(2), 73-79. http://dx.doi.org/10.1108/13563289910268106

George, W. (1990). Internal marketing and organisational behaviour: a partnership in developing customer conscious employees at every level. Journal of Business Research, 20, 63-70. http://dx.doi.org/10.1016/0148-2963(90)90043-D

Gombeski, W., Day, R., Fay, W., \& Lowery, M. (1992). Physician peer review surveys: A management tool for improving quality of patient care. Journal of Health Care Marketing, 12(2), 52-59.

Gounaris, S. (2006). Internal market orientation and its measurement. Journal of Business Research, 59(4), 432-448. http://dx.doi.org/10.1016/j.jbusres.2005.10.003 
Gummesson, E. (1987). Using internal marketing to create a new culture. The case of Ericsson quality. Journal of Business and Industrial Marketing, 2(3), 23-28. http://dx.doi.org/10.1108/eb006032

Harrison, D., Price, K., \& Bell, M. (1998). Beyond relational demography: time and the effects of surface- and deep-level diversity on work group cohesion. Academy of Management Journal, 41(1), 96-107. http://dx.doi.org/10.2307/256901

Hemsley-Brown J. V., \& Oplatka, I. (2006). Universities in a competitive global marketplace: a systematic review of the literature on higher education marketing. International Journal of Public Sector Management, 19(4), 316-338. http://dx.doi.org/10.1108/09513550610669176

Hogg, G., Dunne, A., \& Carter, S. (1998). Investing in People: Internal Marketing and Corporate Culture. Journal of Marketing Management, 14, 879-895. http://dx.doi.org/10.1362/026725798784867563

Ian, N. L., Gordon, E. G. (2010). Internal market orientation and market-oriented behaviors. Journal of Service Management, 21(3), 321-343. http://dx.doi.org/10.1108/09564231011050788

Jaworski, B., \& Kohli, A. (1993). Marketing orientation: antecedents and consequences. Journal of Marketing. 57, 53-70. http://dx.doi.org/10.2307/1251854

Jerome, L., \& Kleiner, B. (1995). Employee morale and its impact on service: What companies do to create a positive service experience. Managing Service Quality, 5(6), 21-25. http://dx.doi.org/10.1108/09604529510104356

Joseph, W. (1996). Internal marketing builds service quality. Journal of Health Care Marketing, 96(16), 54.

Kane, E., \& Kelley, E. (1992). Implementing the Marketing Concept: Linking Quality, Marketing and Value. Working Paper No. 2, CSMM, Florida Atlantic University.

Kaiser, H. (1974). An index of factorial simplicity. Psychometrika, 39, 31-36. http://dx.doi.org/10.1007/BF02291575

Keaveney, M., \& Clifford, E. (1997). The Student Satisfaction and Retention Model (SSRM). Working paper, University of Colorado at Denver.

Keller, S., Lynch, D., Ellinger, A., Ozment, J., \& Calantone, R. (2006). The impact of internal marketing efforts in distribution service operations. Journal of business Logistics, 27, 109-137. http://dx.doi.org/10.1002/j.2158-1592.2006.tb00243.x

Lau, R. (2000). Quality of work life and performance An ad hoc investigation of two key elements in the service profit chain model. International Journal of Service Industry Management, 11(5), 422-437

LeBlanc, P., and Mulvey, W. (1998). How American Workers See the Rewards of Work. Compensation and Benefits Review, 30(1), 24-28. http://dx.doi.org/10.1177/088636879803000104

Liao, H., \& Chuang, A. (2004). A multilevel investigation of factors influencing employee service performance and customer outcomes. Academy of Management Journal, 47, 41-58. http://dx.doi.org/10.2307/20159559

Lings, 1. (2004). Internal market orientation: Construct and consequences. Journal of Business Research, 57(4), 405-413. http://dx.doi.org/10.1016/S0148-2963(02)00274-6

Lings, I., \& Greenley, G. (2009). The impact of internal and external market orientations on firm performance. Journal of Strategic Marketing, 17(1), 41-53. http://dx.doi.org/10.1080/09652540802619251

MacStravic, R. (1985). Internal Marketing for Hospitals. Health Marketing Quarterly, 3, 47-54. http://dx.doi.org/10.1300/J026V03N02_0

Martin, J., Martin, B., \& Grbac, B. (1998). Employee involvement and market orientation in a transition economy: importance, problems and a solution. Journal of Managerial Issues, 10(4), 485-502.

McClelland, D., \& Burnham, D. (1976). Power is the great motivator. Harvard Business Review, 54(2), 100-110.

Meyer, J., \& Herscovitch, L. (2001). Commitment in the workplace, toward a general model. Human Resource Management Review, 11(3), 299-326. http://dx.doi.org/10.1016/S1053-4822(00)00053-X

Mills, P., \& Ungson, G. (2001). Internal market structures: Substitutes for hierarchies. Journal of Service Research, 3(3), 252-264. http://dx.doi.org/10.1177/109467050133006

Mohr-Jackson, I. (1991). Broadening the market orientation: An added focus on internal customers. Human Resources Management, 30(4), 455-467. http://dx.doi.org/10.1002/hrm.3930300403

Mosley, R. (2007). Customer Experience, Organizational Culture and the Employer Brand. Journal of Brand 
Management, 15(2), 123-134. http://dx.doi.org/10.1057/palgrave.bm.2550124

Murrow, J. M., \& Carol, A. (2003). Marketing Health Services, 23(4), 28.

Papasolomou-Doukakis, I., \& Kitchen, J. (2004). Internal marketing in UK banks: conceptual legitimacy or window dressing?". International Journal of Bank Marketing, 22(6), 421-452. http://dx.doi.org/10.1108/02652320410559349

Peltier, J., Drago, W., \& Schibrowsky, J. (2003). Virtual communities and the assessment of online marketing education. Journal of Marketing Education, 25, 260-276. http://dx.doi.org/10.1177/0273475303257762

Pervaiz, M., \& Ahmed, K. (2000). Advances in the internal marketing concept: definition, synthesis and extension. Journal of Services Marketing, 14(6), 449-462. http://dx.doi.org/10.1108/08876040010347589

Pfau B., Detzel, D., \& Geller, A. (1991). Satisfy your internal customers. Journal of Business Strategy, 12(6), 9-13. http://dx.doi.org/10.1108/eb039449

Rafiq, M., \& Ahmed, P. (1993). The Scope of Internal Marketing: Defining The Boundaries Between Marketing and IT. Journal of Marketing Management, 9(3), 219-232. http://dx.doi.org/10.1080/0267257X.1993.9964234

Sakires, J., Doherty, A., \& Misener, K. (2009). Role ambiguity in voluntary sport organizations. Journal of Sport Management, 23, 615-643.

Sánchez, P., Elena, S., \& Castrillo, R. (2006). The Intellectual Capital Report of Universities. Guidelines for disclosing IC information.

Sasser, W., \& Arbeit, S. (1976). Selling Jobs in the Service Sector. Business Horizon, 61-62.

Schneider, B., White, S., \& Paul, M.C. (1998) Linking Service Climate and Customer Perceptions of Service Quality: Test of a Causal Model. Journal of Applied Psychology, 83(2), 150-163. http://dx.doi.org/10.1037/0021-9010.83.2.150

Scovotti, C., \& Peltier, J. (2005). Participant satisfaction with the vocational rehabilitation process: A micro perspective of relationship dimensions. Health Marketing Quarterly, 22(4), 3-26.

Spector, P. (1997). Job Satisfaction: Application, Assessment, Causes, and Consequences. United Kingdom: Sage Publications Ltd.

Tansuhaj, P., Wong, J., \& McCullough, J. (1987). Internal and external marketing: effect on Customer satisfaction in banks in Thailand. International Journal of Bank Marketing, 5(3), 73-83. http://dx.doi.org/10.1108/eb010812

Wasmer, D., \& Brunner, G. (1991). Using organisational culture to design internal marketing strategies. Journal of Services Marketing, 5(1), 35-46. http://dx.doi.org/10.1108/08876049110035468

Wetzel, C., Kneebone, L., Woloshynowych, M., Moorthy, K., \& Darsy, D. (2006). The effects of stress on surgical performance. The American Journal of Surgery, 191(1), 5-10. http://dx.doi.org/10.1016/j.amjsurg.2005.08.034

Zangaro, G., \& Soeken, K. (2007). A meta-analysis of nurses' job satisfaction. Research in Nursing and Health, 30(4), 445-458. http://dx.doi.org/10.1002/nur.20202

Zhou, K., Li, J., Zhou, N., \& Su, C. (2008). Market orientation, job satisfaction, product quality, and firm performance: evidence from China. Strategic Management Journal, 29(8), 985-1000. http://dx.doi.org/10.1002/smj. 700

\section{Copyrights}

Copyright for this article is retained by the author(s), with first publication rights granted to the journal.

This is an open-access article distributed under the terms and conditions of the Creative Commons Attribution license (http://creativecommons.org/licenses/by/3.0/). 